\title{
HARMONISASI HUKUM NASIONAL DI BIDANG KORUPSI DENGAN UNITED NATIONS CONVENTION AGAINST CORRUPTION
}

(National Law Harmonization of Corruption with The United Nations Convention against Corruption)

\author{
Mosgan Situmorang \\ Pusat Penelitian dan Pengembangan Sistem Hukum Nasional \\ Badan Pembinaan Hukum Nasional \\ Jl. Mayjen Sutoyo Nomor 10 Cililitan Jakarta \\ Email: mosgansit@yahoo.com
}

Naskah diterima: 15 Oktober 2014; revisi: 17 Nopember 2014; disetujui: 28 Nopember 2014

\begin{abstract}
Abstrak
Berbagai upaya pemberantasan korupsi telah dilakukan sejak lama namun belum memberikan hasil sebagaimana yang diharapkan. Tindak pidana korupsi diatur antara lain dalam KUHP yang bersifat umum atau lex generalis dan undangundang yang dibuat khusus untuk penanggulangan korupsi seperti undang-undang tindak pidana korupsi maupun undang-undang tindak pidana suap. Disamping itu masih terdapat konvensi Internasional seperti United Nations Convention Against Corruption Tahun 2003. Seperti pemerintahan terdahulu, pemerintahan Jokowi juga mempunyai program tentang pemberantasan korupsi yang sudah dimuat dalam Rancangan Teknokrat Jokowi. Dalam rancangan itu dimuat strategi pemberantasan korupsi yang dilakukan melalui harmonisasi perundang-undangan korupsi dengan konvensi internasional. Penelitian ini dilakukan dengan metode normatif yuridis untuk membahas peraturan apa saja yang terkait dengan pemberantasan korupsi serta bagaimanakah harmonisasi peraturan perundang-undangan di bidang korupsi dengan ketentuan United Nations Convention Against Corruption. Dari penelitian dapat disimpulkan bahwa masih terdapat ketidakharmonisan antara peraturan perundang-undangan di bidang korupsi dengan konvensi Internasional pemberantasan korupsi sehingga perlu segera dilakukan harmonisasi peraturan perundang-undangan nasional dengan konvensi Internasional di bidang korupsi dan strategi yang lebih jitu dan penegakan hukum yang lebih tegas dalam pemberantasan dan pencegahan korupsi ke depan.
\end{abstract}

Kata Kunci: pemberantasan korupsi, strategi, harmonisasi

\begin{abstract}
Various corruption eradication efforts have been done for a long time. Yet the result has not been as expected. Corruption is set in Criminal code as lex generalis and other laws made specifically for the prevention of corruption, such as Law of corruption and bribery laws. There are also International conventions such as the United Nations Convention Against Corruption in 2003. Just like the previous government, The President Jokowi's governance also has programs in eradicating corruption which are already loaded in the draft of Jokowi's Technocrats. Those draft consist of strategy to combat corruption through harmonization of Regulations on Corruption with international conventions on corruption. This research was conducted using normative juridis method by discussing any regulations that are associated with the eradication of corruption and how the harmonization of the laws and regulations in the field of corruption with the provisions of the United Nations Convention against Corruption. From this research, it can be concluded that there is disharmony between the legislation in the field of corruption and the International Conventions Against Corruption so that is why harmonization of national legislation with international conventions in the field of corruption should be made and accurately strategies and law enforcement in combating and prevent corruption in the future should be more strict.
\end{abstract}

Keywords: corruption eradication, strategy, harmonization 


\section{A. Pendahuluan}

Dalam pelaksanaan pembangunan nasional ternyata selain telah memberikan hasil-hasil positif, juga menimbulkan dampak negatif yaitu tumbuh suburnya Korupsi, Kolusi, dan Nepotisme (KKN), lebih jauh korupsi telah merugikan negara baik secara kualitatif maupun kuantitatif dan pada gilirannya hak-hak ekonomi dan sosial rakyat telah dirampas secara semena-mena oleh korupsi. Berbagai upaya pemberantasan korupsi telah dilakukan sejak lama baik secara preventif maupun represif. Namun belum memberikan hasil sebagaimana yang diharapkan. Upaya preventif yang yang telah dilakukan oleh pemerintah untuk pemberantasan korupsi telah dimulai dengan Undang-Undang Nomor 3 Tahun 1971 tentang Pemberantasan Korupsi yang merupakan pengganti Undang-Undang Nomor 24 Tahun 1960 tentang Pengesahan, Penuntutan, dan Pemeriksaan Tindak Pidana Korupsi. Undang-Undang Nomor 24 Tahun 1960 tersebut merupakan pengganti peraturanperaturan yang mendahului sebelumnya yakni peraturan Penguasa perang Pusat tanggal 16 April 1958 Nomor Prp/Perppu/D13/58 dan Peraturan Perang Kepala Staf Angkatan Laut tertanggal 17 April 1958 NomorZ/1/17. Seiring dengan perkembangannya kebutuhan dan taraf hidup rakyat Indonesia maka pemerintah memberlakukan Undang-Undang Nomor 11 Tahun 1980 tentang Pemberantasan Tindak Pidana Suap. ${ }^{1}$ Dengan demikian sebenarnya Pemerintah telah berbuat banyak di dalam upaya pemberantasan korupsi dan sudah dilakukan jauh sebelum KPK terbentuk. ${ }^{2}$

Sejumlah instrumen nasional lainnya telah dikeluarkan juga yaitu Tap MPR No XI/MPR/ RI Tahun 1998 dan kemudian diikuti oleh produk lainnya, antara lain Undang-Undang Nomor 28 Tahun 1998 tentang penyelenggaraan Negara Yang Bersih dan bebas dari KKN, Undang-Undang Nomor 31 Tahun 1999 tentang Pencegahan dan Pemberantasan Tindak Pidana Korupsi juncto Undang-Undang Nomor 20 Tahun 2001 dan TAP MPR No. VII / MPR/RI Tahun 2001 tentang Rekomendasi Arah Kebijakan pemberantasan dan Pencegahan KKN dan Undang-Undang Nomor 30 Tahun 2002 tentang Pembentukan suatu Komisi pemberantasan Tindak Pidana Korupsi (KPTPK) yang sekarang lebih dikenal dengan Komisi Pemberantasan Korupsi (KPK). Produk Hukum Nasional tersebut bertujuan untuk terwujudnya kepemerintahan yang baik (good governance) dan bebas KKN (Korupsi, Kolusi, dan Nepotisme).

Selain pembentukan hukum nasional juga terdapat instrumen internasional yaitu "Convention Against Corruption PBB" yang telah disahkan DPR pada 21 Maret 2006 menjadi Undang-Undang. DPR menilai bahwa ratifikasi atas Konvensi PBB Antikorupsi 2003 itu mempunyai makna yang strategis karena dapat dijadikan sebagai payung hukum dalam pemberantasan korupsi, dengan cara melakukan kerjasama internasional. Pemerintah menyatakan bahwa Konvensi PBB Antikorupsi 
2003 mengandung terobosan dalam mengatasi tindak pidana korupsi. Dengan pengesahan konvensi ini, kerjasama internasional dalam memerangi tindak korupsi dan kejahatan internasional lainnya akan dipermudah. Ruang gerak para koruptor untuk bersembunyi dan melarikan hasil kejahatannya ke sejumlah negara kian sempit. Selain itu, dengan disahkannya Konvensi PBB ini korupsi diakui sebagai kejahatan global dan akan ditangani dengan semangat kebersamaan. ${ }^{3}$

Indonesia adalah negara hukum, konsep negara hukum secara historis dipengaruhi perkembangan tentang negara dan kedaulatan, khususnya teori kedaulatan negara yang kemudian mendapat reaksi dari teori kedaulatan hukum. Kekuasaan yang dimiliki negara tidak bersifat mutlak dan kekuasaan tersebut harus didasarkan pada hukum serta digunakan untuk melaksanakan fungsi dan tujuannya yaitu kesejahteraan masyarakat ${ }^{4}$. Hal ini mempunyai makna bahwa negara tidak dapat semena-mena dalam melakukan suatu tindakan kepada warganya walaupun dengan tujuan yang baik. Akan tetapi semua tindakan haruslah berdasarkan hukum termasuk dalam penindakan terhadap koruptor.

Pemerintahan lama yang dipimpin oleh SBY yang telah berlangsung selama 10 (sepuluh) tahun telah berlalu dan digantikan oleh pemerintahan baru yang dipimpin Jokowi. Seperti dalam pemerintahan sebelumnya secara politis pemerintahan Jokowi pun bertekad akan melaksanakan pemberantasan korupsi dengan sunggun-sungguh, seperti yang sudah dikumandangkan saat kampanye sebelum ia terpilih menjadi presiden.

Perkembangan pemberantasan korupsi semakin meningkat dengan meningkatnya penanganan perkara korupsi dari segi kuantitas dan kualitas, yang tidak hanya fokus pada perkara dalam skala kecil tetapi juga dalam skala besar dan berdampak luas. Namun, masih ditemui kendala dalam hal rendahnya komitmen dan belum meratanya pemahaman di tingkat pusat dan daerah. Upaya pencegahan dan pemberantasan korupsi ini masih menjadi salah satu permasalahan pokok dalam pencegahan dan pemberantasan korupsi.

Hasil evaluasi berdasarkan berbagai survei nasional dan internasional menunjukkan bahwa suap secara khusus maupun korupsi secara umum merupakan faktor yang menghambat daya saing Indonesia sehingga masih dibutuhkan arah kebijakan dan strategi untuk meningkatkan upaya pencegahan dan pemberantasan korupsi di Indonesia. ${ }^{5}$ Dengan demikian sasaran pencegahan dan pemberantasan korupsi adalah menurunnya tingkat korupsi serta meningkatnya efektivitas pencegahan dan pemberantasan korupsi. Dalam rangka mewujudkan sasaran tersebut maka diperlukan arah kebijakan dan strategi dalam upaya untuk meningkatkan efektivitas pencegahan dan pemberantasan korupsi yang salah satunya dilaksanakan melalui harmonisasi peraturan perundangundangan di bidang korupsi. Upaya untuk meningkatkan efektivitas pencegahan dan

Ibid, hlm. 6.

Mia Amiati Iskandar, Perluasan Penyertaan Dalam Tindak Pidana Korupsi Menurut UNCATOC 2000 dan UNCAC 2003, (Jakarta: Referensi, 2013), hlm.55.

5 Lihat Draft RT RPJM 2015-2019 Jokowi. 
pemberantasan korupsi dilaksanakan melalui harmonisasi peraturan perundang-undangan di bidang tindak pidana korupsi dengan mengacu pada ketentuan United Nations Convention Against Corruption yang telah diratifikasi oleh Indonesia. Oleh karena itu maka yang diangkat sebagai permasalahan utama penelitian ini adalah peraturan apa saja yang terkait dengan tindak pidana korupsi; serta bagaimanakah harmonisasi peraturan perundang-undangan di bidang korupsi dengan ketentuan United Nations Convention Against Corruption.

\section{B. Metode Penelitian}

Penelitian ini adalah penelitian normatif yuridis, dengan demikian maka data yang digunakan dalam Penelitian ini adalah data sekunder. Bahan penelitian adalah bahan primer berupa Undang-Undang dan peraturan perundang- undangan lainnya serta bahan sekunder berupa buku dan bahan pustaka yang lain seperti artikel dalam jurnal, baik yang terbit dalam bentuk buku maupun yang terdapat dalam internet. Di samping itu juga dipakai bahan tertier berupa kamus. Semua bahan tersebut dipelajari dengan seksama lalu disajikan menjadi data dalam bentuk uraian. Kemudian data tersebut dianalisis secara kualitatif untuk menjawab permasalahan dalam penelitian yang pada akhirnya menghasilkan kesimpulan dan saran.

\footnotetext{
Lihat TAP MPR NomorXI/MPR/1998
}

\section{Pembahasan}

\section{Peraturan Perundang-undangan Nasional Yang Terkait Pemberantasan Tindak Pidana Korupsi}

Terdapat beberapa peraturan perundangundangan yang terkait dengan pemberantasan korupsi. Di antaranya adalah Tap MPR No.XI/ MPR/RI Tahun 1998 tentang Penyelenggaran Negara yang Bersih dan Bebas Korupsi, Kolusi, dan Nepotisme. ${ }^{6}$ Selain itu terdapat UndangUndang Nomor 25 Tahun 2002 tentang Perubahan atas Undang-Undang Nomor 15 Tahun 2002 tentang Tindak Pidana Pencucian Uang; Undang-Undang Nomor 30 Tahun 2002 tentang Komisi Pemberantasan Tindak Pidana Korupsi; Undang-Undang Nomor 15 Tahun 2002 tentang Tindak Pidana Pencucian Uang; Undang-Undang Nomor 31 Tahun 1999 tentang Pemberantasan Tindak Pidana Korupsi juncto Undang-Undang Nomor 20 Tahun 2001; Undang-Undang Nomor 28 Tahun 1999 tentang Penyelenggaraan Negara yang Bersih dan Bebas dari Korupsi, Kolusi, dan Nepotisme; serta Peraturan Pemerintah Nomor 24 Tahun 2004 tentang Kedudukan Protokoler dan Keuangan Pimpinan dan Anggota Dewan Perwakilan Rakyat Daerah dan Peraturan Pemerintah Nomor 71 Tahun 2000 tentang Tata Cara Pelaksanaan Peran Serta Masyarakat dan Pemberian Penghargaan Dalam pencegahan dan Pemberantasan Tindak Pidana Korupsi. Di samping itu terdapat juga Instruksi Presiden Nomor 5 Tahun 2004 tentang Percepatan Pemberantasan Korupsi.

Korupsi menurut Undang-Undang Nomor 31 tahun 1999 sebagaimana telah diubah dengan 
Undang-Undang Nomor 20 tahun 2001 adalah perbuatan yang dikonsepsikan sebagai berikut: ${ }^{7}$

a. Secara melawan hukum melakukan perbuatan memperkaya diri sendiri atau orang lain atau suatu korporasi yang dapat merugikan keuangan Negara atau perekonomian Negara;

b. Dengan tujuan menguntungkan diri sendiri, atau orang lain,atau suatu korporasi menyalahgunakan keuangan, kesempatan atau sarana yang ada padanya karena jabatan atau kedudukan yang dapat merugikan keuangan Negara atau perekonomian Negara.

c. Termasuk kejahatan yang tercantum dalam Pasal 201, 209, 387, 388, 415, 416, 417, 418, 419, 420,324, 436 KUHPidana Memberi hadiah atau janji kepada pegawai negeri dengan mengingat kekuasaan atau wewenang yang melekat pada jabatan atau kedudukannya, atau oleh pemberi hadiah, atau janji dianggap melekat pada jabatan atau kedudukan tersebut.

d. Melanggar ketentuan undang-undang yang secara tegas menyatakan bahwa pelanggaran terhadap ketentuan undangundang tersebut sebagai tindak pidana korupsi.

e. Melakukan percobaan, pembantuan atau permufakatan jahat untuk melakukan tindak pidana korupsi.

f. Di luar wilayah Negara Republik Indonesia yang memberikan bantuan, kesempatan sarana atau keterangan untuk terjadinya tindak pidana korupsi.

Sementara itu menurut Kamus Hukum Black's Law Dictionary, korupsi adalah: "An act done with an intention give some advantage inconsistent with official duty and the rights of order. The act an official or fiduciary person who unlawfuly and wrongfuly use his station or character to procure some benefit for himself of for another person contrary to duty and the rights of others"8) (suatu perbuatan yang dilakukan dengan maksud untuk memberikan suatu keuntungan yang tidak sesuai dengan kewajiban resmi dan hak-hak dari pihak lain. Perbuatan dari seorang pejabat atau kepercayaan yang secara melanggar hukum dan secara salah menggunakan jabatannya atau karakternya untuk mendapatkan suatu keuntungan untuk dirinya sendiri atau untuk orang lain, berlawanan dengan kewajibannya dan hak-hak dari pihak lain").

Menurut Prof. Syed Husein Alatas guru besar Universitas Singapura ada 7 (tujuh) tipologi korupsi yaitu: ${ }^{9}$

a. Transactive Corruption yakni jenis korupsi dengan kesepakatan timbal balik

b. Nepotistic corruption

c. Extortive corruption atau korupsi dengan cara memeras

d. Investif coruption yakni memberi jasa atau barang demi keuntungan dimasa depan

e. Defensive corruption yakni memaksa orang lain terlibat dalam proses korupsi

Lihat Undang-Undang Nomor 31 Tahun 1999 jo Undang-Undang Nomor 20 Tahun 2001 Tentang Tindak Pidana Korupsi.

8 Black's Law Dictionary, Ninth Edition West Thomson reuters business 2009.

9 Seperti di kutip dalam IGM Nurdjana, Sistem Hukum Pidana dan bahaya laten korupsi, (Yogyakarta: Pustaka Pelajar), hlm. 23. 
f. Outgenic corruption atau korupsi yang dilakukan seorang diri

g. Supportive corruption yakni korupsi dukungan

Dalam Undang-Undang Republik Indonesia Nomor 31 Tahun 1999 jo Undang-Undang Nomor 20 Tahun 2001 terdapat 8 (delapan) spirit moral sebagai berikut:

a. Mengikis komunitas yang selalu mengedepankan "supremasi" paternalistic secara tidak benar melalui ketentuan tentang larangan suap terhadap pegawai negeri (Pasal 5 dan Pasal 6). ${ }^{10}$

b. Menghidupkan kembali control internal sejak dini, dimulai dari lingkungan keluarga melalui ketentuan yang membolehkan Jaksa Penuntut Umum untuk melakukan perampasan atas harta kekayaan yang terbukti berasal dari korupsi (Pasal 33, 34, 38 ayat (5).

c. Memberdayakan kontrol sosial ekonomi eksternal melalui ketentuan tentang Peran Serta Masyarakat dalam pemberantasan tindak pidana korupsiyang mengaturtentang perlindungan hukum untuk memberikan jawaban atas pelaporan dimaksud dalam jangka waktu 30 hari kerja sejak diterimanya permintaan atas pelaporan tersebut (Bab V, Pasal 41 sampai Pasal 42).

d. Menumbuhkan budaya malu (shame culture) baik di dalam kalangan masyarakat luas maupun di kalangan penyelenggara Negara melalui ketentuan tentang kewajiban tersangka/terdakwa kasus korupsi untuk

menerangkan asal usul harta kekayaannya atau suami, istrinya atau keponakannya dihadapan penyidik (Pasal 28, Pasal 37 ayat (3) dan ayat (4)).

e. Menimbulkan hambatan-hambatan moral (moral straints) untuk melakukan tindak pidana korupsi melalui ketentuan tentang ancaman pidana minimum khusus dan maksimum yang tinggi, bahkan sampai ancaman pidana mati dan adanya ketentuan mengena pidana tambahan yang sangat berat bagi tersangka / terdakwa pelaku tindak pidana korupsi (Pasal 2, Pasal 3, Pasal 5 sampai dengan Pasal 11).

f. Melembagakan budaya anti korupsi secara terus menerus dan berkesinambungan di kalangan masyarakat maupun di kalangan penyelenggara Negara melalui ketentuan tentang perlunya pembentukan Komisi Pemberantasan Korupsi yang harus dibentuk dengan Undang-Undang (Pasal 43), Peran Serta Masyarakat dan kewajiban pemberian informasi yang benar dan transparan tentang kasus-kasus tindak pidana korupsi (Pasal 41).

g. Menumbukan budaya kooperatif di kalangan penegak hukum terutama kepolisian dan kejaksaan dalam pemberantasan tindak pidana korupsi melalui ketentuan tentang pembentukan Tim Penyidik Gabungan di bawah koordinasi Jaksa Agung (Pasal 27). Tim Penyidik Gabungan ini merupakan embrio dari Komisi Pemberantasan Korupsi. 
h. Melembagakan koordinasi horizontal dengan instansi atau lembaga non penegak hukum terutama untuk membuka rekening tersangka atau terdakwa secara luas (Pasal 29 dan Pasal 3). ${ }^{11}$

Spirit moral yang terkandung di dalam Undang-Undang Nomor 31 tahun 1999 sebagaimana diuraikan di atas diharapkan menjadi hambatan-hambatan (moral restrains) bagi perorangan atau korporasi agar tidak melakukan korupsi. Hambatan-hambatan moral tersebut perlu dituangkan ke dalam bentuk normatif, dimana terdapat sanksi administratif, sanksi perdata atau juga sanksi pidana sebagaima dimuat dalam rumusan pasal-pasal Undang-Undang Nomor 31 tahun 1999.

Undang-Undang Nomor 31 Tahun 1999 jo Undang-Undang Nomor 20 tahun 2001 dalam tatanan hukum pidana nasional, merupakan undang-undang pidana khusus yaitu undangundang tindak pidana murni yang memuat ketentuan-ketentuan khusus yang berbeda atau menyimpang dari ketentuan umum sebagaimana telah diatur baik dalam Kitab Undang-Undang Hukum Pidana (KUHP) maupun di dalam Undang-Undang RI Nomor 8 Tahun 1981 tentang Hukum Acara Pidana atau dikenal dengan KUHAP.

Undang-Undang Nomor 31 Tahun 1999 jo Undang-Undang Nomor 20 tahun 2001 memiliki 12 (duabelas) karakteristik yang menonjol yang membedakan dengan Undang-Undang Nomor 3 Tahun 1971. Perbedaan yang menonjol tersebut adalah: a. Bahwa tindak pidana korupsi dirumuskan secara formal (delik formal) bukan delik material dimana pengembalian kerugian Negara tidak menghapuskan penuntutan pidana terhadap terdakwa, melainkan hanya sebagai faktor yang meringankan pidana;

b. Dicantumkan pengaturan tentang korporasi sebagai subyek hukum di samping perorangan;

c. Dicantumkan pengaturan tentang wilayah berlakunya atau yurisdiksi criminal yang dapat diberlakukan keluar batas territorial Indonesia (extra territorial jurisdiction);

d. Dicantumkan pengaturan tentang sistem pembuktian terbalik terbatas atau berimbang atau "balanced burden of proof".

e. Dicantumkan pengaturan tentang ancaman pidana dengan minimum khusus di samping ancaman maksimum;

Terdapat ancaman pidana mati sebagai unsure pemberatan dalam hal-hal tertentu seperti Negara dalam keadan bahaya, terjadi bencana alam nasional, tindak pidana korupsi dilakukan sebagai pengulangan tindak pidana atau Negara dalam keadaan krisis ekonomi dan moneter, ${ }^{12}$

g. Dicantumkan pengaturan tentang penyidikan gabungan dalam perkara tindak pidana korupsi dan sulit pembuktiannya di bawah koordinasi Jaksa Agung;

h. Dicantumkan pengaturan tentang penyidikan ke dalam rahasia bank yang lebih luas, diawali dengan pembekuan rekening tersangka atau terdakwa (freezing) yang dapat dilanjutkan dengan penyitaan (seizure);

11 Pasal 29 mengatur tentang kewajiban bank untuk memberikan informasi nasabah dalam rangka penyidikan.

12 Lihat Pasal 2 ayat(2) Undang-Undang Nomor 31 tahun 1999 jo Undang-undang nomor 20 Tahun 2001. 
i. Dicantumkan pengaturan tentang peran serta masyarakat sebagai sarana kontrol sosial dipertegas dan diperluas sehingga perlindungan hokum terhadap terhadap saksi pelapor lebih optimal dan efektif mirip dengan "whistle blower act";

j. Undang-Undang PTPK tahun 1999 telah mengamanatkan pembentukan Komisi Pemberantasan Korupsi (KPK) yang bersifat independen dengan keanggotaan terdiri dari unsur pemerintah dan masyarakat (profesional) serta pengangkatannya harus mendapat persetujuan DPR;

k. Dimuat ketentuan mengenai pegawai negeri yang lebih luas dibanding dengan undangundang tentang kepegawaian dan peraturan perundang-undangan lainnya yang berkaitan dengan kepegawaian;

I. Dimuat ketentuan mengenai pidana tambahan yang lebih luas dibandingkan dengan pidana tambahan sebagaimana telah diatur baik dalam Kitab UndangUndang Hukum Pidana maupun dalam Undang-Undang Pemberantasan Tindak Pidana Korupsi Tahun 1971.

Salah satu cara yang paling ampuh untuk memberantas korupsi adalah dengan beban pembuktian terbalik. Akan tetapi beban pembuktian terbalik oleh Jaksa Penuntut Umum kepada terdakwa, akan berpotensi menimbulkan pelanggaran Hak Asasi Manusia yakni ketentuan khusus tentang praduga tidak bersalah. ${ }^{13}$

Pemberantasan korupsi secara global kini sudah merupakan komitmen pemerintah di seluruh Negara. Hal ini terbukti dengan telah diselenggarakannya dua kali konferensi dunia tentang Strategi Global Antikorupsi yang telah diikuti oleh para Kepala Pemerintahan dan pejabat setingkat Menteri dari kurang lebih 150 negara dan diselenggarakannya di Washington DC Amerika Serikat pada tahun 1999 dan di Den Haag, Belanda pada tahun 2001 dan pada finalnya pada bulan Desember tahun 2003 dengan disahkannya dan telah ditandatanganinya oleh beberapa anggota PBB yaitu United National Convention Against Corruption di Merida Mexico. ${ }^{14}$ Komitmen untuk melakukan pemberantasan korupsi se dunia tersebut telah menegaskan kembali pentingnya kerjasama seluruh Negara untuk memberantas korupsi yang bersifat nasional, lintas batas territorial maupun yang berdampak internasonal.

Dalam hal ini disadari bahwa usaha pemberantasan korupsi tidak semata-mata merupakan persoalan hukum, tetapi juga merupakan persoalan sosial, ekonomi dan politik, sehingga upaya pemberantasannya pun harus bersifat komprehensif dan multidisipliner. Untuk mempersiapkan usaha pemberantasan korupsi yang efisien dan efektif pemerintah telah menyusun Strategi Nasional Pemberantasan Korupsi yang bertumpu pada 4 (empat) pendekatan yaitu: 1) Pendekatan Hukum, 2) Pendekatan Budaya, 3) Pendekatan Ekonomi, dan 4) Pendekatan Sumber Daya Manusia dan Sumber Daya Keuangan (Human resources and financial resources). 
Dalam pendekatan budaya pemerintah telah berhasil mempersiapkan program pemberdayaan masyarakat bekerjasama dengan unsur Koalisi Organisasi Non-Pemerintah (ORNOP). Sejalan dengan keragaman budaya yang telah tumbuh dan berkembang dalam masyarakat Indonesia, maka keragaman tersebut telah mengakibatkan perbedaan sikap kelompok etnik yang satu dengan kelompok etnik lainnya. Perbedaan itu di samping merupakan keunikan tersendiri akan tetapi juga berdampak terhadap kehidupan masingmasing kelompok etnik tersebut. Ada kelompok etnik yang mengunggulkan kebendaan yang dikaitkan dengan status sosial seseorang dalam masyarakat dan ada pula kelompok etnik yang lebih mementingkan hubungan sosial yang bertitik tolak pada kekerabatan tanpa mengaitkan dengan status sosial dan kekayaan yang dimiliki seseorang. Menghadapi keragaman budaya dan perbedaan sikap kelompok-kelompok etnik tersebut, strategi pemberantasan korupsi harus diarahkan pada pemberdayaan dan kesadaran masyarakat mengenai bahaya dan dampak korupsi terhadap tatanan kehidupan bermasyarakat, berbangsa dan bernegara.

Salah satu pendekatan utama dalam memandang korupsi adalah perspektif yang dibangun dari teori pilihan rasional, teori ini memandang manusia adalah makhluk rasional yang selalu berusaha mengejar kepentingannya sendiri. Manusia adalah agen sosial yang dalam tindakan sosialnya selalu berusaha untuk memaksimalkan keuntungan bagi dirinya sendiri. Dalam kasus korupsi, maka perspektif teori pilihan rasional penyebabnya adalah penghasilan kurang sehingga perlu tambahan uang dari praktik korupsi. ${ }^{15}$ Korupsi adalah salah satu bentuk white collar crime karena biasanya dilakukan oleh mereka dari kalangan atas yang berkedudukan sosial tinggi, terhormat dan dilakukan dalam pekerjaannya. ${ }^{16}$

Pendekatan ekonomi dalam strategi pemberantasan korupsi seharusnya ditujukan untuk meningkatkan kemampuan ekonomi yang dilaksanakan oleh pemerintah dengan membentuk satuan tugas (task force) yang disebut "Task Force of Good Corporate Governance" yang bertujuan meningkatkan prinsip-prinsip transparansi dan akuntabilitas dalam komunitas bisnis. Hal ini disebabkan perkembangan ekonomi nasional tidak hanya ditentukan oleh keberhasilan konglomerat dan kalangan golongan ekonomi lemah melainkan juga dituntut oleh komunitas bisnis melakukan persaingan usaha yang jujur dan anti monopilistik. Berdasarkan hal tersebut telah ditetapkan beberapa perubahan peraturan perundang-undangan yang mendukung Good Corporate Govenance tersebut.

Menurut Satjipto Raharjo, umtuk mendirikan negara hukum memerlukan suatu proses yang panjang, tidak hanya peraturan perundang-undang saja yang harus ditata kelola dengan baik, namum dibutuhkan sebuah kelembagaan yang kuat dan kokoh dengan kewenangan kerenangan uang luar biasa dan

15 J. Danang Widiyoko, Oligarki dan Korupsi Politik Indonesia, (Malang: Setara Press, 2013), hlm. 25.

16 Sutherland, White Collar Crime, Dalam Kristian, Hukum Pidana Korporasi, (Bandung: CV. Nuansa Mulia, 2014) hlm. 28 
independen bebas dari intimidasi atau campur tangan eksekutif dan legislatif ${ }^{17}$

Pembentukan Komisi Pemberantasan Tindak Pidana Korupsi yang lebih dikenal dengan Komisi Pemberantasan Korupsi (KPK) yang diperintahkan berdasarkan Undang-Undang Nomor 31 Tahun 1999 sehingga melahirkan Undang-Undang Nomor 30 Tahun 2002 tentang Komisi Pemberantasan Tindak Pidana Korupsi merupakan suatu strategi pemberantasan korupsi yang menetapkan bahwa komisi dapat melakukan penyelidikan, penyidikan dan penahanan terhadap penyelenggara Negara dan pejabat tinggi Negara yang sudah menjadi tersangka tanpa perlu meminta izin terlebih dahulu pada Presiden, komisi dapat mengambilalih tugas dan wewenang penyelidikan dan penyidikan dari Kepolisian atau Kejaksaan jika kedua instansi tersebut terbukti secara kuat tidak ada keinginan atau tidak ada kemampuan untuk melakukan tugas tersebut, komisi juga dapat membuka jalan kembali kasus korupsi yang telah memperoleh putusan hukum yang tetap jika terbukti kemudian terdapat tindak pidana dalam prosess peradilan atau kasus tersebut di masa lalu dan komisi dapat memerintahkan Bank untuk memblokir atau membuka rekening keuangan tersangka korupsi tanpa perlu meminta izin terlebih dahulu dari Bank Indonesia.

\section{Harmonisasi Hukum Pidana Internasioanal Terhadap Konvensi Internasional Pemberantasan Korupsi}

Harmonisasi hukum Pidana terhadap Konvensi Pemberantasan Korupsi, dalam tulisan ini lebih terfokus pada: (a) pemberlakuan yurisdiksi Undang-Undang Nomor 31 Tahun 1999 juncto Undang-Undang Nomor 20 Tahun 2001 baik di dalam maupun di luar batas teritorial, (b) kerjasama internasional dalam pemberantasan korupsi baik mealui ekstradisi dan mutual assistance in criminal matters, ${ }^{18}$ atau melalui bentuk kerjasama lainnya yang diakui dalam Konvensi PBB Merida Mexico 2003.

\section{a. Masalah Pemberlakuan Undang- Undang Nomor 31 Tahun 1999 juncto Undang-Undang Nomor 20 Tahun 2001 di Dalam dan di Luar Batas Teritoril}

Undang-Undang Nomor 31 Tahun 1999 juncto Undang-Undang Nomor 20 Tahun 2001 merupakan undang-undang khusus dan sekaligus "lex specialist" terhadap KUHP sehingga dibolehkan adanya ketentuan khusus dan menyimpang dari ketentuan dalam KUHP karena sifat tindak pidana korupsi yang sangat luar biasa, yaitu merupakan pelanggaran hak-hak ekonomi dan social rakyat. Namun demikian kekhususan tersebut tidak dapat menyimpang dari ketentuan dalam Buku I KUHP tentang ketentuan umum karena asas-asas hukum umum Hukum Pidana yang telah diakui oleh masyarakat internasional, seperti asas legalitas dan asas nebis in idem. Penyimpangan hukum tersebut juga dapat dibenarkan oleh 
hukum internasional sepanjang mengenai pemberlakuan yurisdiksi hukum pidana sebagaimana telah ditegaskan pula di dalam ketentuan Pasal 9 KUHP, bahwa berlakunya pasal-pasal 2-5, 7 dan 8 dibatasi oleh hal yang dikecualikan yang diakui hukum internasional. Ketentuan inimengandung makna bahwa hukum nasional (KUHP) tidak boleh bertentangan dengan hukum internasional, akan tetapi hukum internasional dapat membatasi berlakunya ketentuan hukum nasional sepanjang ketentuan hukum internasional tersebut telah diakui oleh pemerintah Indonesia.

Dalam kaitan yurisdiksi ini, Undang-Undang Nomor 31 Tahun 1999 juncto Undang-Undang Nomor 20 Tahun 2001 dapat dilakukan keluar batas teritorial dengan berdasarkan kepada asas nasionalitas aktif sebagaimana diatur dalam Pasal 3 KUHP jika dalam kasus korupsi terlibat Warga Negara Indonesia yang bertempat tinggal di Negara lain atau melarikan diri ke Negara lain. Implementasi ketentuan ini memang diakui dapat memunculkan konflik yurisdiksi hukum pidana antara Indonesia dengan Negara yang bersangkutan, dan dalam praktek hukum internasional konflik ini sering terjadi dan sudah ada beberapa yurisprudensi yang berhasil ditetapkan oleh International Court of Justice (ICJ) seperti kasus Lotus (tahun 1927) dimana ICJ telah menyampaikan pendapatnya sebagai berikut: "all or nearly all the system of law extend their action to offences commited outside the territory of the state which adopts them and do so in ways which vary from state to state". ${ }^{19}$

Dalam kaitan konflik yurisdiksi hukum pidana, hukum internasional dalam praktik telah menyediakan beberapa sarana hukum yang dianggap memadai, seperti ekstradisi atau mutual assistance in criminal matters, dua sarana hukum yang telah sejak lama digunakan oleh Negara-negara yang terkait dalam konflik yurisdiksi hukum tersebut. Untuk menghindari konflik yurisdiksi tersebut, KUHP Belanda tahun 1881, staatsblad 35 yang terakhir diubah dengan Undang-Undang tanggal 24 Mei 1996, Staatsblad 276, telah memasukkan ketentuan baru, Titel VIII, "Extinction of the right to prosecute and of punishment" (Pasal 68) yang dikenal sebagai "res judicata foreign judgement". Pasal 68 berbunyi sebagai berikut:

Ayat 1: "Exept in cases in which judgement are susceptible to review, no person my be prosecuted again for an offence in respect of which a court in the Netherlands, the Netherlands Antilles or Aruba has rendered final judgement on the substance of the changed against him".

Ayat 2: "If the final judgmenet has been rendered by another court, new proceedings against the person for the same offence may not take place in the case of:

(1) Acquittal or dismissal of the charges.

(2) Conviction, if punishment has been imposed, followed by complete enforcement, pardons or lapse of time.

Ayat 3 : "No person may be prosecuted for an offence which has been irrevocably disposed of, inrelation to him, by the fulfillment of a condition set by the

\footnotetext{
19 Romli Atmasasmita, Pengantar Hukum Pidana Internasional, (Bandung: PT Refika Aditama, 2000), hlm. 22.
} 
competent authorities of a foreign state to prevent prosecution". 20

\section{b. Kerjasama Hukum Dalam Pencegahan dan Pemberantasan Tindak Pidana Korupsi}

Konvensi Merida Mexico 2003 juga telah memasukkan ketentuan yurisdiksi yang diperluas (Pasal 50) dengan menetapkan diberlakukannya dua cara pemberlakuan, yaitu: pertama yang bersifat "mandatory" untuk memberlakukan asas territorial baik mengenai "Locus delict" maupun dengan pengakuan kapal laut atau pesawat udara sebagai "territory", dan cara kedua bersifat "optional" dengan 4 (empat) opsi yurisdiksi criminal, yaitu:

1) Korupsi dilakukan terhadap warga negara dari negara yang bersangkutan;

2) Korupsi dilakukan oleh warga Negara dari Negara atau oleh "stateless" (tanpa kewarganegaraan) yang bertempat tinggal di Negara yang bersangkutan.

3) Mereka yang melakukan "laundering proceed of corruption" yang dilakukan di Negara lain tetapi berdampak terhadap kepentingan Negara yang bersangkutan, dan 4) Korupsi tersebut dilakukan dan bertentangan dengan hukum Negara yang bersangkutan.

Ketentuan tersebut di atas hanya akan efektif dilengkapi dengan ketentuan mengenai kerjasama hukum seperti ekstradisi, transfer of sentenced person, mutual legal assistance, transfer of criminal proceedings dan lain-lain. ${ }^{21}$

Dalam konteks hubungan bilateral/ multilateral dengan Negara-negara ASEAN maka ketentuan mengenai yurisdiksi dan kerjasama hukum sebagaimana diuraikan di atas seharusnya juga dipertimbangkan untuk dimasukkan ke dalam RUU KUHP dan ditetapkan satu bab khusus tentang yurisdiksi atau kerjasama internasional khususnya ketentuan mengenai "Mutual Legal Assistance in Criminal Matters" (Bantuan Timbal Balik Dalam Masalah Pidana). Langkah-langkah ini akan mempererat kerjasama hukum antara Indonesia dan Negara ASEAN lainnya, sekaligus melengkapi langkah pemerintah untuk mencegah dan memberantas tindak pidana korupsi yang bersifat transnasional termasuk tindakan pembekuan dan penyitaan hasil korupsi.

Disadari bahwa untuk melangkah kepada kebijakan criminal untuk menyatakan pengakuan putusan pengadilan asing masih diperlukan langkah-langkah harmonisasi hukum dan sinkronisasi hukum antar Negara-negara ASEAN tersebut.

\section{c. Karakteristik Konvensi PBB tentang Pemberantasan Korupsi}

Konvensi PBB 2003 memuat 8 (delapan) bagian, ${ }^{22}$ dan ketentuan yang sangat signifikan terhadap perkembangan pembaharuan 
perundang-undangan nasional alam pemberantasan korupsi adalah: Chapter II, Preventive Measures, Chapter IV, International Cooperation, Chapter V, Asset Recovery, dan Chapter VII, Mechanism for Implementation.

Keempat ketentuan tersebut merupakan karakteristik mendasar yang membedakannya dengan ketentuan dalam Undang-Undang Nomor 31 Tahun 1999 tentang Pemberantasan Tindak Pidana Korupsi juncto Undang-Undang Nomor 20 Tahun 2001 tentang Perubahan atas Undang-Undang Nomor 31 Tahun 1999. Perbedaan signifikan pertama adalah Konvensi PBB 2003 merupakan payung hukum internasional dalam pemberantasan korupsi khususnya pengembalian aset-aset hasil korupsi di Negara lain, sedangkan UndangUndang Nomor 31 Tahun 1999 juncto UndangUndang Nomor 20 Tahun 2001 merupakan payung hukum nasional untuk meningkatkan efektifitas pemberantasan korupsi pada level nasional (Indonesia). Perbedaan kedua, terletak pada penempatan peranan hubungan sektor swasta dan pejabat publik termasuk pejabat publik Negara asing dan Organisasi Internasional PBB dalam korupsi lebih menonjol dalam Konvensi PBB 2003 dibandingkan dengan Undang-Undang Nomor 31 Tahun 1999 juncto Undang-Undang Nomor 20 Tahun 2001 yang lebih menitikberatkan pada system "pembuktian terbalik" dalam upaya mencegah kerugian Negara sebagai akibat tindak pidana korupsi. Perbedaan ketiga, Konvensi PBB 2003 menganut paradigma internasional dengan mengutamakan harmonisasi model system hukum "Civil Law" dan "Common Law", sedangkan Undang-Undang Nomor 31 Tahun 1999 juncto Undang-Undang Nomor 20 Tahun 2001 menganut paradigma nasional yang mengutamakan model system hukum "Civil Law". Perbedaan keempat, terletak pada tujuan Konvensi PBB 2003 yang lebih mengutamakan penguatan kerjasama internasional, adalah untuk meningkatkan efektifitas pemberantasan korupsi yang dinilai sudah tidak efektif dengan instrument hukum yang biasa. Kerja sama itu luas sekali ruang lingkupnya karena dapat berupa kerja sama dalam mencegah dan memberantas korupsi, bantuan teknis dalam mencegah dan memerangi korupsi, yang termasuk di dalam pendidikan dan pelatihan para penegak hukum yang disponsori oleh PBB. Inilah yang mesti dimanfaatkan dan diterapkan oleh KPK, kepolisian, kejaksaan dan hakim. ${ }^{22}$

\section{d. Implikasi Ratifikasi Konvensi PBB tentang Pemberantasan Korupsi 2003}

\section{United Nation Convention Against Corruption}

(UNCAC) yang telah ditandatangani bersama dan disahkan oleh PBB pada bulan Desember 2003 adalah merupakan salah satu proses dari upaya masyarakat internasional dalam hal pemberantasan korupsi. Sampai dengan 14 Nopember 2014 ada 140 negara yang sudah meratifikasi UNCAC termasuk negara negara industri kaya yang tergabung dalam kelompok G8 seperti Jerman, Italia, Jepang, Inggris, Prancis, Rusia, Kanada dan Amerika Serikat. ${ }^{23}$ Hal ini merefleksikan komitmen kuat masyarakat internasional terutama Negara-negara Asia dan

22 Andi Hamzah, Pemberantasan Korupsi Melalui Hukum Pidana Nasional dan Internasional, (Jakarta: PT Raja Grafindo Persada, 2012), hlm.

23 https://www.unodc.org/unodc/en/treaties/CAC/signatories.html (diakses tanggal 28 Nopember 2014) 
Afrika sebagai "Victim State" untuk sungguhsungguh memberantas korupsi yang diyakini sebagai salah satu sumber utama kemiskinan di Negara-negara berkembang.

Pemerintah Indonesia yang ikut aktif dalam sidang-sidang Konvensi PBB 2003 tidak ragu-ragu untuk meratifikasi konvensi tersebut, dan segera melakukan kajian yang mendalam mengenai implikasi hukum peratifikasian konvensi tersebut ke dalam sistem hukum nasional. Pemerintah Indonesia tidak ragu karena langkah dan komitmen pemerintah untuk memberantas korupsi dengan sarana hukum nasional dan internasional akan menjadi lebih kuat. Bagi bagi bangsa Indonesia ratifikasi konvensi tersebut merupakan kebijakan yang tepat karena cara tersebut diharapkan dapat menyelamatkan nasib bangsa ini dari cengkeraman para koruptor. Selain itu juga didasarkan atas pertimbangan, bahwa kerusakan bangsa Indonesia sebagai akibat dari korupsi sudah berlangsung sejak tahun 1970-an terutama sejak mengalirnya bantuan Negara donor ke dalam pembangunan ekonomi Indonesia tanpa adanya ruang kontrol masyarakat yang luas terhadap kinerja para penyelenggara Negara.

Proses ratifikasi merupakan pernyataan suatu Negara untuk tunduk dan terikat kepada ketentuan yang sudah disepakati oleh masyarakat internasional baik dengan reservasi maupun tidak dengan reservasi. Peratifikasian dan implementasi Konvensi PBB 2003 ke dalam hukum nasional jelas memerlukan tindak lanjut karena berimplikasi kepada pelaksanaan kewajiban-kewajiban pemerintah Indonesia untuk melaksanakan substansi konvensi tersebut dan menyampaikan laporan tahunan perkembangan pemberantasan korupsi kepada PBB.

Untuk masa ke depan dengan peratifikasian konvensi tersebut dan implementasinya ke dalam hukum nasional serta hak-hak yang dimiliki oleh Indonesia sebagai Negara peratifikasi maka tidak ada lagi "imunitas" dan "tempat berlindung" (save heaven) para koruptor dimanapun dan kemanapun koruptor tersebut melarikan diri dan menyembunyikan aset-aset hasil korupsinya. Untuk memperkuat pencegahan dan penyitan asset hasil korupsi maka Konvensi PBB 2003 juga telah mewajiban setiap Negara anggota memiliki Undang-Undang Pencucian Uang. ${ }^{24}$ Berdasarkan uraian ini jelas bahwa Konvensi PBB 2003 telah memberikan pilihan sarana hukum internasional yang bersifat komprehensif dan tidak bersifat "one single factor approach" dalam pemberantasan korupsi.

Pendekatan tersebut telah menuntut Konvensi PBB memasukkan ketentuan mengenai pembentukan suatu lembaga independen untuk memberantas korupsi di setiap Negara. Pembentukan Komisi Pemberantasan Korupsi berdasarkan Undang-Undang Nomor 30 Tahun 2002 sangat relevan dan merupakan wujud komitmen nasional Indonesia untuk duduk sama tinggi dengan bangsa-bangsa lain di dunia dalam mencegah terjadinya pelanggaran hakhak ekonomi dan sosial yang mengakibatkan kemiskinan yang semakin meluas di tanah air.

Ada beberapa impilikasi terhadap Undangundang korupsi dengan diratifikasinya Konvensi UNCAC 2003 antara lain adalah:

a. Berkaitan dengan konsep dan system hukum material yang telah lama dianut

24 Indonesia sudah mempunyai Undang-Undang Nomor 8 Tahun 2010 Tentang Tindak Pidana Pencucian Uang. 
dalam sistem hukum nasional, yaitu konsep standar mengenai unsur-unsur tindak pidana korupsi yang menitikberatkan sifat melawan hukum dari suatu perbuatan, dan konsep "daad-dader strafrecht" karena Konvensi PBB 2003 hanya menitikberatkan kepada 3 (tiga) unsur, yaitu: mengetahui (knowledge), kesengajaan (intent), dan adanya tujuan (purpose). Selain itu konvensi PBB 2003 bertujuan untuk melindungi kepentingan pihak ketiga yang beritikad baik di samping kepentingan Negara.

Sebagai konsekuensinya maka rumusan unsur tindak pidana korupsi di dalam Undang-Undang Nomor 31 Tahun 1999 jo Undang-Undang Nomor 20 tahun 2001 yang menekankan adanya kerugian Negara perlu dikaji kembali, mungkin juga perlu dipertimbangkan unsur "kerugian pihak ketiga yang beritikad baik". Selain itu dalam Konvensi PBB 2003 masih digunakan pengertian istilah "bribery" yang diartikan sebagai "corruption" dalam kaitan hubungan swasta dan pejabat publik. Sedangkan dalam Undang-Undang Nomor 31 Tahun 1999 jo Undang-Undang Nomor 20 tahun 2001 pengertian istilah "bribery" atau "suap" dimasukkan sebagai salah satu jenis tindak pidana korupsi dan tidak ditujukan khusus kepada subyek yang terlibat di dalamnya.

b. Konvensi PBB 2003 menganut pendekatan komprehensif dalam menghadapi korupsi yang melibatkan dua atau lebih Negara yang sudah tentu melibatkan juga Warga Negara Asing sehingga titik berat pengaturannya terletak pada prosedur bagaimana melacak dan menyita serta mengembalikan asset hasil korupsi dari suatu Negara yang "menikmatinya" ke Negara korban (state's Victim) $)^{25}$. Sedangkan Undang-Undang Nomor 31 Tahun 1999 jo Undang-Undang Nomor 20 tahun 2001 hanya mengandalkan pengaturan mengenai bagaimana kualifikasi tindak pidana korupsi dapat diperluas sehingga kerugian Negara sekecil apapun dapat dicegah.

c. Pengaturan mengenai kerjasama yang lebih mengemuka dalam Konvensi PBB 2003 dibandingkan dengan ketentuan di dalam Undang-Undang Nomor 31 Tahun 1999 jo Undang-Undang Nomor 20 tahun 2001 sehingga implementasi konvensi tersebut ke dalam hukum nasional menuntut ruang pengaturan yang lebih luas mengenai bidang tersebut.

d. Implikasi keempat, diperlukan proses kriminalisasi terhadap perbuatan pelanggaran hukum baru sebagaimana yang telah diatur dalam Bab III tentang "Criminalization and Law Enforcement" dalam United Nations Convention Against Corruption 2003, termasuk di antaranya: "Bribery of national public officials, Bribery of foreign public officials and officials of public international organization, embezzlement, missapropriation or other diversion of property by a public officials and trading in influence".

Dari beberapa implikasi tersebut di atas, salah satu hal yang paling urgent adalah masalah asset recovery atau pengembalian asset hasil tindak pidana korupsi. terdapat beberapa ketentuan yang dapat digunakan sebagai dasar hukum pengembalian aset hasil tindak pidana

Asset Recovery atau pengembalian aset diatur dalam BAB V UNCAC 2003. 
korupsi umpamanya dalam KUHAP dikatakan bahwa salah satu benda yang dapat disita dari tersangka adalah benda atau tagihan tersangka atau terdakwa yang sebagian atau seluruhnya diduga diperoleh dari hasil tindak pidana. ${ }^{26}$ Sebagai akibat dari penyitaan tersebut maka selanjutnya hakim dapat memutuskan bawa benda atau tagihan tersebut dapat dirampas untuk negara. Ketentuan ini adalah bersifat umum, bukan khusus dalam konteks pengembalian asset hasil tidak pidana korupsi.

Dengan demikian aturan tersebut masih memiliki kelemahan-kelemahan karena, fokus utama ketentuan itu adalah pengembalian aset hasil tindak pidana korupsi di dalam negeri. Tidak ada ketentuan yang mengatur mekanisme pengembalian aset hasil tindak pidana korupsi yang ditempatkan di luar negeri. Disamping itu juga belum ada peraturan perundang-undangan yang dapat digunakan sebagai landasan hukum serta wewenang untuk melaksanakan kerja sama internasional khusus dalam pengembalian aset hasil tindak pidana korupsi sebagai implemantasi UNCAC 2003. Pengembalian Asset pada hakikatnya adalah kewajiban moral yang merupakan salah satu kebajikan sosial untuk bertindak dalam rangka mencapai kesejahteraan umum, baik dalam skala nasional maupun internasional ${ }^{27}$

Mekanisme dalam melakukan proses pengembalian aset hasil tindak pidana korupsi, yaitu: pertama dengan melakukan pelacakan, selanjutnya aset yang sudah dilacak dan diketahui kemudian dibekukan, terakhir, aset yang dibekukan lalu disita dan dirampas oleh badan berwenang dari negara di mana aset tersebut berada, dan kemudian dikembalikan kepada negara tempat aset tersebut diambil melalui mekanisme-mekanisme tertentu. Kesepakatan tentang pengembalian aset tercapai karena kebutuhan untuk mendapatkan kembali aset-aset hasil tindak pidana korupsi sebagaimana harus direkonsiliasikan dengan hukum dan prosedur dari negara-negara yang dimintai bantuan.

Cara paling mudah dalam melakukan proses pengembalian aset yang berada di luar yurisdiksi negara korban adalah melalui bantuan hukum timbal balik (Mutual Legal Assistance). Ketika aset-aset hasil tindak pidana korupsi ditempatkan di luar negeri, negara korban yang diwakili oleh penyelidik, penyidik, atau lembaga otoritas dapat meminta kerjasama dengan negara penerima untuk melakukan proses pengembalian aset. hal ini sesuai dengan apa yang diatur dalam Pasal 46 UNCAC, di mana negara-negara penerima aset harus memberikan bantuan kepada negara korban dalam rangka proses pengembalian aset. Bahkan dalam hal negara-negara dengan sistem perbankan yang sangat tertutup, oleh karena itu UNCAC memberikan kemudahan negara-negara korban untuk dapat menelusuri atau mengakses sistem perbankan suatu negara untuk memperoleh informasi atas aset hasil tindak pidana korupsi. Hal ini diatur dengan jelas dalam Pasal 46 ayat (8).

Masalah lain yang perlu diperhatikan adalah agar dalam pembahasan rancangan KUHP maupun KUHAP disamping harus sejalan

26 Lihat Pasal 39 Kitab Undang-Undang Hukum Acara Pidana (KUHAP) Tahun 1981.

27 Purwaning M. Yanuar, Pengembalian Aset Hasil korupsi, Berdasarkan Konvensi PBB Anti Korupsi 2003 Dalam Sistem Hukum Indonesia, (Bandung: PT. Alumni, 2007), hlm. 67. 
dengan Undang-Undang Pemberantasan Korupsi maupun Undang-Undang KPK harus juga diselaraskan dengan ketentuan Konvensi Internasional khususnya United Nations Convention Against Corruption Tahun 2003 yang sudah kita ratifikasi. Karena senyatanya konvensi tersebut sudah mengikat dan menjadi bagian hukum nasional.

\section{Penutup}

Walapun sudah 8 (delapan) tahun Indonesia meratifikasi Konvensi PBB Anti Korupsi Tahun 2003 (United Nations Convention Against Corruption), akan tetapi masih banyak ketentuan-ketentuan Hukum Nasional di bidang korupsi yang belum diselaraskan dengan konvensi tersebut, umpamanya mengenai kriminalisasi terhadap pejabat publik asing dan swasta, demikian juga dalam hal asset recovery belum ada dasar hukum yang kuat yang dapat digunakan khusus dalam pengembalian asset hasil korupsi yang dibawa atau disimpan ke luar negeri. Yang ada saat ini baru perjajian bilateral terhadap beberapa negara berupa MLA (Mutual Legal Asistance) yang bersifat umum. Sehingga pengembalian asset hasil korupsi belum bisa maksimal. Oleh karena itu perlu membuat aturan-aturan untuk menselaraskan Konvensi PBB Anti Korupsi Tahun 2003 (United Nations Convention Against Corruption dengan peraturan peraturan pemberantasan korupsi dalam hukum nasional Indonesia dalam Undang- Undang Nomor 39 Tahun 1999 jo Undang- Undang Nomor 20 tahun 2001 maupun dalam KUHP yang akan datang.

Dalam rangka mempercepat pengembalian asset (asset recovery) perlu dibentuk suatu lembaga di bawah struktur Komisi Pemberantasan Korupsi (KPK) yang bertugas untuk mengurus hal-hal yang berkaitan dengan pengembalian aset negara yang diduga milik pelaku tindak pidana korupsi yang berada di luar negeri, di mana terdiri dari unsur Interdep atau lintas instansi antara lain: Kepolisian, Kejaksaan, Kemenlu, Kemenkumham, Bank Indonesia, dan pakar Hukum.

\section{DAFTAR PUSTAKA}

\section{Buku}

Hamzah, Andi, Pemberantasan Korupsi Melalui Hukum Pidana Nasional dan Internasional, (Jakarta: PT Raja Grafindo Persada, 2012)

Asian Development Bank (ADB), Executive Summary dalam Progress Fight Against Corruption in Asia and Pasific, (Manila, 2001)

Nurdjana, IGM, Sistem Hukum Pidana dan Bahaya Laten Korupsi, Perpektif Tegaknya Keadilan Melawan Mafia Hukum, (Yoygakarta: Pustaka Pelajar, 2010)

Widiyoko, J. Danang, Oligarki dan Korupsi Politik Indonesia, (Malang: Setara Press, 2013

Kristian, Hukum Pidana Korporasi, (Bandung: CV. Nuansa Mulia, 2014)

Effendy Marwan, Korupsi dan Strategi Nasional Pencegahan Serta Pemberantasannya, (Jakarta: GP Press group, 2013)

Iskandar, Mia Amiati, Perluasan Penyertaan Dalam Tindak Pidana Korupsi Menurut UNCATOC 2000 dan UNCAC 2003, (Jakarta: Referensi, 2013)

Monang Siahaan, Korupsi Penyakit Sosial yang Mematikan, (Jakarta: PT Elex Media Komputindo, Kompas Gramedia, 2013)

Purwaning M. Yanuar, Pengembalian Aset Hasil korupsi Berdasarkan Konvensi PBB Anti Korupsi 2003 Dalam Sistem Hukum Indonesia, (Bandung: PT. Alumni, 2007)

Stessen, Guy, Money Laundering A New Intenational Law Enforcement Model, (Cambridge University Press, 2000)

\section{Makalah / Artikel / Prosiding / Hasil Penelitian}

Badan Pembinaan Hukum Nasional, Laporan Akhir Tim Penelitian Tentang Aspek Hukum Nasional dan Internasional Pemberantasan Korupsi, (Jakarta: BPHN, 2006)

\section{Internet}


https://www.unodc.org/unodc/en/treaties/CAC/ signatories.html (diakses tanggal 28 Nopember 2014)

\section{Peraturan}

TAP MPR NomorXI/MPR/1998 tentang Penyelenggaran Negara yang Bersih dan Bebas Korupsi, Kolusi, dan Nepotisme

Undang-Undang Nomor 25 Tahun 2002 tentang Perubahan atas Undang-Undang Nomor 15 Tahun 2002 tentang Tindak Pidana Pencucian Uang

Undang-Undang Nomor 30 Tahun 2002 tentang Komisi Pemberantasan Tindak Pidana Korupsi

Undang-Undang Nomor 15 Tahun 2002 tentang Tindak Pidana Pencucian Uang

Undang-Undang Nomor 20 Tahun 2001 tentang Tindak Pidana Korupsi
Undang-Undang Nomor 31 Tahun 1999 tentang Pemberantasan Tindak Pidana Korupsi

Undang-Undang Nomor 28 Tahun 1999 tentang Penyelenggaraan Negara yang Bersih dan Bebas dari Korupsi, Kolusi, dan Nepotisme

United Nation Convention Against Corruption, 2003

Peraturan Pemerintah Nomor 24 Tahun 2004 tentang Kedudukan Protokoler dan Keuangan Pimpinan dan Anggota Dewan Perwakilan Rakyat Daerah

Peraturan Pemerintah Nomor 71 Tahun 2000 tentang Tata Cara Pelaksanaan Peran Serta Masyarakat dan Pemberian Penghargaan Dalam pencegahan dan Pemberantasan Tindak Pidana Korupsi

Instruksi Presiden Nomor 5 Tahun 2004 tentang Percepatan Pemberantasan Korupsi. 